\title{
Works of Heidegger Cited in the Notes
}

The abbreviations listed below are used to cite both the German and English editions. I have generally quoted from published English translations, although I have made occasional changes in the interest of consistent terminology. In particular, 'vorhanden' and its derivatives have been translated consistently by 'extant' and its derivatives, instead of Macquarrie and Robinson's 'present-at-hand'.

Note references give the page numbers in the translation first, followed by the page numbers in the German edition.

A.W.P. "Die Zeit des Weltbildes." 1950. In Holzwege (Frankfurt am Main: Klostermann, 1963), pp. 69-104.

"The Age of the World Picture." Translated by William Lovitt. In The Question concerning Technology and Other Essays (New York: Harper \& Row, 1977), pp. 115-154.

B.P. Die Grundprobleme der Phänomenologie. 1927. Frankfurt am Main: Klostermann, 1975.

The Basic Problems of Phenomenology. Translated by Albert Hofstadter. Bloomington: Indiana University Press, 1982.

B.T. Sein und Zeit. 1927. Tübingen: Niemeyer, 1957.

Being and Time. Translated by John Macquarrie and Edward Robinson. New York: Harper \& Row, 1962.

E.O.P. "Das Ende der Philosophie und die Aufgabe des Denkens.” 1964. In Zur Sache des Denkens (Tübingen: Niemeyer, 1969), pp. 61-80.

"The End of Philosophy and the Task of Thinking." Translated by Joan Stambaugh. In On Time and Being (New York: Harper \& Row, 1972), pp. 55-73. 
H.C.T. Prolegomena zur Geschichte des Zeitbegriffs. 1925. Frankfurt am Main: Klostermann, 1979.

History of the Concept of Time: Prolegomena. Translated by Theodore Kisiel. Bloomington: Indiana University Press, 1985.

I.D. Identitüt und Differenz. 1957.

Identity and Difference. Translated by Joan Stambaugh. New York: Harper \& Row, 1969. Dual-language text.

K.P.M. Kant und das Problem der Metaphysik. 1929. Frankfurt am Main: Klostermann, 1973.

Kant and the Problem of Metaphysics. Translated by James Churchill. Bloomington: Indiana University Press, 1962.

L.H. Brief über den Humanismus. 1946. In Wegmarken (Frankfurt am Main: Klostermann, 1976), pp. 313-362.

Letter on Humanism. Translated by Frank Capuzzi and J. Glenn Gray. In Basic Writings (New York: Harper \& Row, 1977), pp. 193242.

M.F.L. Metaphysische Anfangsgrunde der Logik im Ausgang von Leibniz. 1928. Frankfurt am Main: Klostermann, 1978.

The Metaphysical Foundations of Logic. Translated by Michael Heim. Bloomington: Indiana University Press, 1984.

M.H.B. "Die Metaphysik als Geschichte des Seins." In Nietzsche II (Pfullingen: Neske, 1961), pp. 399-457.

"Metaphysics as History of Being." Translated by Joan Stambaugh. In The End of Philosophy (New York: Harper \& Row, 1973), pp. 154.

M.H.C. Martin Heidegger im Gesprach. Freiburg: Karl Alber, 1970.

Martin Heidegger in Conversation. Translated by B. S. Murthy. New Delhi: Arnold Heinemann, 1977.

O.E.T. Von Wesen der Wabrheit. 1930. In Wegmarken (Frankfurt am Main: Klostermann, 1976), pp. 13-44.

On the Essence of Truth. Translated by John Sallis. In Basic Writings (New York: Harper \& Row, 1977), pp. 117-141.

O.G.C. "Nur noch ein Gott kann uns retten." In Der Spiegel, May 1976, pp. 193-219.

"Only a God Can Save Us." Translated by William Richardson. In Heidegger: The Man and His Thought (Chicago: Precedent, 1981), pp. 45-72.

Q.C.T. "Die Frage nach der Technik." 1954. In Vorträge und Aufsätze (Pfullingen: Neske, 1954), pp. 13-44.

"The Question concerning Technology." Translated by William Lovett. In The Question concerning Technology and Other Essays (New York: Harper \& Row, 1977), pp. 3-35. 
S.H.B. "Entwürfe zur Geschichte des Seins als Metaphysik." In Nietzsche II (Pfullingen: Neske, 1961), pp. 458-480.

"Sketches for a History of Being as Metaphysics." Translated by Joan Stambaugh. In The End of Philosophy (New York: Harper \& Row, 1973), pp. 55-74.

S.S. $\quad$ "Protokoll zu einem Seminar über den Vortrag 'Zeit und Sein."” 1969. In Zur Sache des Denkens (Tübingen: Niemeyer, 1969), pp. 27-60.

"Summary of a Seminar on the Lecture 'Time and Being." "Translated by Joan Stambaugh. In On Time and Being (New York: Harper \& Row, 1972), pp. 25-54.

T.B. "Zeit und Sein." 1968. In Zur Sache des Denkens (Tübingen: Niemeyer, 1969), pp. 1-25.

"Time and Being." Translated by Joan Stambaugh. In On Time and Being (New York: Harper \& Row, 1972), pp. 1-24. 
